JURNAL AL BAYAN: JURNAL JURUSAN PENDIDIKAN BAHASA ARAB

p-ISSN 2086-9282 | e-ISSN 2549-1229

\title{
The Use of Creative Board Media in Improving Arabic Writing Skills
}

\author{
Isop Syafei $^{1 *}$, Aini Ummu Syukriya ${ }^{2}$ \\ ${ }^{1}$ Arabic Education Study Program Universitas Islam Negeri Sunan Gunung Djati Bandung, Indonesia \\ ${ }^{2}$ SMA P.B Soedirman 1 Bekasi, Indonesia
}

Article History:

Received : January 15, 2020

Revised : February 18, 2020

Accepted : March 20, 2020

Published : June 01, 2020

\section{Keywords:}

Effective; Efficient; Foreign

Language; Learning Process

*Correspondence Address: isop.syafei@uinsgd.ac.id

\begin{abstract}
The learning process of writing Arabic occasionally finds difficulties in examining the validity of writing or answers from the students as soon as possible evenly in the classroom, because of limited time. The teacher is required to be able to manage learning as well as possible, so that the interaction between students and teacher in the process of teaching activities runs optimally and comprehensively to all students in the class. This research aims to determine the efforts of the Arabic language teacher at Islamic senior high school of P.B. Soedirman 1 Bekasi in the use of creative board media to improve the Arabic writing skills of the students. The method used in this research is experimental method. The subject of research are students of class $\mathrm{X}$ KBC (Kelompok Belajar Cepat - Fast Learning Group) majoring in social studies (16 students), and students of class X majoring in science (22 students). Data collection technique used in this assignment project is documentation. In analyzing data, the researcher uses deductive analysis techniques. The results showed that; 1) the Arabic teacher has sought to use effective and efficient media in the learning process, 2) students can also get benefit from the Creative Board media to be more enthusiastic in practicing Arabic writing. The crative board media is hence very feasible to be implemented in the process of learning a foreign language.
\end{abstract}

\section{Introduction}

Arabic competencies that must be possessed by students in this millennial era are interactive communication skills, where students are forged to have communication skills in accordance with the themes that exist in everyday life. In the learning process occasionally find difficulties in examining the validity of the writing or answers of students as soon as possible evenly in the classroom, because learning is limited by time. While teachers are required to be able to manage learning as well as possible. Therefore teachers are required to innovate in learning foreign languages. To achieve that goal, it is necessary to use learning media that can motivate students to improve their foreign language skills. One of the ways is by using Creative Board media. 
Creative Board is a simple two-dimensional learning media made of thick cardboard or used cardboard sheets cut to the desired size, and then coated with colored folio paper, also coated with clear white duct tape, so that it can be written on it with non-permanent markers and can be deleted again for subsequent writing. Learning media as its function are all things that can be used to channel messages and stimulate mind, arouse enthusiasm, attention, and willingness of students, so that it can encourage the learning process in students. ${ }^{1}$ Creative Board as a learning media facilitates educators and students in conveying information on learning activities in Arabic writing skills that are effective and efficient.

In learning Arabic writing skills, particularly at part of composing (Insya') oriented on students' ability to express their thoughts in the form of ideas, messages, feelings into written language, teachers often have difficulty in examining students' works. $^{2}$ This is due to constrained learning time which is very limited, so the learning time has often run out while the verification of each student's writing has not been completely finished. Therefore, only several students' writings can be assessed carefully, and given feedback, so that the students whose writings have not been verified tend to be ignored. This situation leads to imbalancement of interactions between teacher and all students. Ideally, writing skill learning results are checked spontaneously right away and given feedback so that the next writing results are minimized errors. ${ }^{3}$

Creative Board learning media is a tool emphasizing students to learn writing quickly and pleasantly, as well as to show the result of students' work to the teacher right away, so as to write the next sentence avoiding the previous mistakes that have been corrected. ${ }^{4}$ The ways to use the Creative Board media are as follows: (1) All students write what is asked of writing activity in the Creative Board media; (2) All students lift the Creative Board together based on instructions; (3) The teacher starts checking

\footnotetext{
1 Acep Hermawan, Metodologi Pembelajaran Bahasa Arab (Bandung: Pt Remaja Rosakarya, 2018), 272.

${ }^{2}$ Nurul Huda, "Komponen-Komponen Pembelajaran Al-Kitâbah Bahasa Arab," Al Mahāra: Jurnal Pendidikan Bahasa Arab, 2016, Https://Doi.Org/10.14421/Almahara.2016.021-01.

${ }^{3}$ Syamsi Setiadi, "Peningkatan Keterampilan Kitabah Aarabiyah Mahasiswa Melalui Metode Tutor Sebaya," Jurnal Al Bayan: Jurnal Jurusan Pendidikan Bahasa Arab, 2017, Https://Doi.Org/10.24042/Albayan.V9i1.1094.

4 Lucy Maryeni, Syarifah Nur Siregar, And Yenita Roza, "Development Of Computer-Based Learning Media Using Mind Map For Learning Mathematics In Topics Of Rectangle And Triangle At Secondary School” 2019, No. July 2019 (2020): 73-84.
} 
directly and gives longer portions for writing that requires more correction. ${ }^{5}$ This is very beneficial for teaching and learning activities because the teacher does not have to check piles of students' books. Verification of writing skills can also be carried out spontaneously. By using this Creative Board learning media, the achievement of students' learning goals can be more effective and efficient, maximally achieved by only using minimal learning components. ${ }^{6}$

The values contained in the use of Creative Board learning media are in line with the basic principles of curriculum development 2013, which confirms that the learning process with a scientific approach and the assessment of learning outcomes based on processes and products through activities: observing, asking, exploring, associating, and communicating. ${ }^{7}$ This is reinforced by the characteristics of the 2013 curriculum as outlined in the basic framework and structure of the curriculum designed to develop a balance between developing spiritual and social attitudes, curiosity, creativity, cooperation, with intellectual and psychomotor abilities. ${ }^{8}$

In the process of learning Arabic writing skills carried out at Islamic Senior High School P.B. Soedirman 1 Bekasi, the use of Creative Board media has been going on for a period of time. Based on the problem analysis of previous writing skills learning, the teacher faces obstacles to build innovations in the use of effective and efficient media avoiding boredom in learning and equitable interaction between teacher and students. ${ }^{9}$ Thus, the use of Creative Board as a medium for learning foreign languages, particularly in this case is Arabic writing skills, will further familiarize them with Arabic and have a sense of pleasure in learning it. ${ }^{10}$

\footnotetext{
${ }^{5}$ Kuo Hung Tseng Et Al., “Using Creative Problem Solving To Promote Students' Performance Of Concept Mapping," International Journal Of Technology And Design Education, 2013, Https://Doi.Org/10.1007/S10798-012-9230-8.

6 Joko Kuswanto And Ferri Radiansah, "Media Pembelajaran Berbasis Android Pada Mata Pelajaran Sistem Operasi Jaringan Kelas Xi," An Nabighoh Jurnal Pendidikan Dan Pembelajaran Bahasa Arab, 2018, Https://Doi.Org/10.32332/An-Nabighoh.V20i01.1131.

7 Hardi Tambunan, "The Effectiveness Of The Problem Solving Strategy And The Scientific Approach To Students' Mathematical Capabilities In High Order Thinking Skills," International Electronic Journal Of Mathematics Education 14, No. 2 (2019): 293-302, Https://Doi.Org/10.29333/Iejme/5715.

8 Siti Mahmudah, "Media Pembelajaran Bahasa Arab," An Nabighoh Jurnal Pendidikan Dan Pembelajaran Bahasa Arab, 2018, Https://Doi.Org/10.32332/An-Nabighoh.V20i01.1131.

9 Syamfa Agny Anggara, "Penerapan Model Project Based Learning Untuk Meningkatkan Kemampuan Menulis Siswa," Arabi: Journal Of Arabic Studies, 2018, Https://Doi.Org/10.24865/Ajas.V2i2.57.

${ }^{10}$ Mohamed Saad Bakry And Hashem Ahmed Alsamadani, "Improving The Persuasive Essay Writing Of Students Of Arabic As A Foreign Language (Afl): Effects Of Self-Regulated Strategy
} 
Previous researches related to the efforts to improve Arabic writing skills of students have been done by several researchers. Some of them are: Nur Indah Latifah and Ali Mudlofir ${ }^{11}$ examine the implementation of magnetic board media to improve students' writing skills. The results of his research show that the application of magnetic media boards can improve students' Arabic writing skills. Sitti Kuraedah ${ }^{12}$ examines the application of Mahabah Kitabah in Arabic learning. This article describes the stages of the application of Mahabah Kitabah in learning Arabic to express ideas and ideas in Arabic writing, namely learning about the procedures for writing, connecting letters, writing words, writing sentences, and writing without text. Syamsi Setiadi ${ }^{13}$ examines the improvement of the skills of students in Arabic through the peer tutoring method. The results of his research show that peer tutoring is proven to be able to improve students' Arabic writing skills, and the learning process can be maximized with existing potential without much teacher involvement.

Muhammad Kamal bin Abdul Hakim, Yumna Rasyid, and Zainal Rafli ${ }^{14}$ researching Writing Skills through the Contextual Learning Approach (Improving Arabic Academic Writing Skills Through Contextual Teaching And Learning Approach). The results of his research show that the contextual learning approach can improve students' academic writing skills and even changes in learning behavior show good criteria by $80 \%$. Nurul Huda ${ }^{15}$ examines the Learning Components of Arabic Al-Kitâbah. This article describes the interrelationship between the components of Arabic language skills, namely listening (istimâ '), speaking (kalâm), reading (qirâ'ah), and writing (kitâbah) which are inseparable from one another and mutually reinforcing.

Ahmad Muradi ${ }^{16}$ examines Arabic writing skills in Indonesia, problems, and solutions. The results of his research show that the use of techniques, methods, and

\footnotetext{
Development," Procedia - Social And Behavioral $\quad$ Sciences, 2015, Https://Doi.Org/10.1016/J.Sbspro.2015.04.742.

${ }^{11}$ Nur Indah Nalaratih And Ali Mudlofir, “ تطبيق وسائل اللوحة المغناطيسية لترقية مهارة الكتابة لتلاميذ الفصل الثامن بمدرسة واحد هاثم المتوسطة سور ابايا 2, No. 2 (2018): 203-12.

${ }^{12}$ Sitti Kuraedah, “Aplikasi Maharah Kitabah Dalam Pembelajaran Bahasa Arab,” Al-Ta'dib, 2015.

${ }^{13}$ Setiadi, "Peningkatan Keterampilan Kitabah Arabiyah Mahasiswamelalui Metode Tutor Sebaya."

${ }^{14}$ Anfal Gulam Et Al., "Writing Skill In Arabic Language Essay In Malaysian Secondary School," International Journal Of Social Science \& Human Behavior Study 2, No. 2 (2015): 169-73, Https://Doi.Org/10.15224/978-1-63248-046-0-111.

${ }^{15}$ Huda, "Komponen-Komponen Pembelajaran Al-Kitâbah Bahasa Arab."

${ }^{16}$ Ahmad Muradi, "Wâqi' Ta'lîm Mahârah Al-Kitâbah Bi Indûnîsiyyâ Musykilatan Wa Hulûlan," Arabiyat: Jurnal Pendidikan Bahasa Arab Dan Kebahasaaraban, 2018, Https://Doi.Org/10.15408/A.V5i1.7795.
} 
learning media for writing Arabic is very effective in improving learning outcomes, and there are alternatives that can solve the problem of learning to write Arabic. (7) Wan Rusli Wan Ahmad, Prof. Dr. Nuraihan Mat Daud ${ }^{17}$ researched about the development of writing skills using Facebook. The results of his research show that the development of Arabic writing skills through the use of Facebook is seen as effective and preferred by students.

Research efforts in Arabic writing skills and their development have been carried out by previous researchers as described above, this article seeks to explore the use of Creative Board media in order to improve Arabic writing skills. This article outlines the efforts that have been made by Arabic language teacher at Islamic Senior High School P.B. Soedirman 1 Bekasi in the use of Creative Board media in improving Arabic writing skills of students from this school. To discuss this case systematically, this article is divided into three parts. The first part discusses the Creative Board learning media. The second part outlines the discourse on Arabic writing skills (maharatul kitabah). The third part is the use of Creative Board learning media to improve Arabic writing skills at Islamic Senior High School P.B. Soedirman 1 Bekasi.

\section{Method}

This research was conducted at Islamic Senior High School P.B. Soedirman 1 Bekasi, Jl. Taman Soka 2 Taman Galaxy Jakasetia, South Bekasi. The subject of research on the use of Creative Board media in improving Arabic writing skills at this school are students of class X KBC (Kelompok Belajar Cepat - Fast Learning Group) majoring in social studies (16 students), and students of class X majoring in science (22 students). Data collection technique used in this assignment project is documentation. The documentation method is a research method for obtaining information by checking and recording the report of existing documents. ${ }^{18}$ In this research, the results of the student assignments were documented in Creative Board learning media. In analyzing data, the

\footnotetext{
${ }^{17}$ Ng Sau Ping And Mahendran Maniam, "The Effectiveness Of Facebook Group Discussions On Writing Performance: A Study In Matriculation College," International Journal Of Evaluation And Research In Education (Ijere), 2015, Https://Doi.Org/10.11591/Ijere.V4i1.4489.

${ }^{18}$ Izzuddin Musthafa And Acep Hermawan, Metodologi Penelitian Bahasa Arab (Konsep Dasar, Strategi, Metode, Teknik) (Bandung: Pt Remaja Rosakarya, 2018). 52.
} 
researcher uses deductive analysis techniques, that indicators of competency achievement become a reference in assessing student's work. ${ }^{19}$

\section{Result and Discussion}

\section{Learning Media of Creative Board}

The Association of Education Communication Technology (AECT) defines media as all forms and channels that can be used for the message distribution process. Media is a component of the process of teaching and learning activities that help students to understand the received information. ${ }^{20}$ Learning media are also positioned as an environmental stimulus that influences students to take action in learning. ${ }^{21}$ Anything can become media if a message of information reaches the recipient. If something does not convey information in the learning process, but only as a device, then it cannot be said as a learning media. ${ }^{22}$ In Arabic, learning media is called al-wasa'il al-ta'limiyah, which means that everything used to facilitate the delivery of Arabic learning material. ${ }^{23}$

Arabic learning media can be physical or non-physical which is used by the teacher as an intermediary to understand the information conveyed by the teacher to students in order to achieve the learning objectives effectively and efficiently. ${ }^{24}$ The classification of learning media in accordance with the ease of procurement are: (1) language as instructions; (2) various types of boards; (3) various types of images; (4) print media; (5) projection media; and (6) electronic media. ${ }^{25}$ From this classification it can be said that the Creative Board learning media is included in the learning media category of various types of boards.

\footnotetext{
${ }^{19}$ Sugiyono, Metode Penelitian Kuantitatif Kualitatif Dan R\&D (Bandung: Alfabeta, 2016).

20 Rosdiana, "Pengembangan Media Pembelajaran Berbasis Komputer," Al-Khwarizmi: Jurnal Pendidikan Matematika Dan Ilmu Pengetahuan Alam, 2018, Https://Doi.Org/10.24256/Jpmipa.V1i2.95.

${ }^{21}$ Teguh Martono Kurniawan And Dwi Nurhayati Oky, "Implementation Of Android-Based Mobile Learning Application As A Flexible Learning Media," International Journal Of Computer Science Issues, 2014.

${ }^{22}$ Vishranti Raut And Prafulla Patil, "Use Of Social Media In Education: Positive And Negative Impact On The Students," International Journal On Recent And Innovation Trends In Computing And Communication, 2016.

${ }^{23}$ Hilmi M Noor, "Penggunaan Media Komik Dalam Pembelajaran Bahasa Arab Materi Hiwar Dan Pengaruhnya Pada Prestasi Siswa Dalam Pembelajaran Bahasa Arab.” (Uin Sunan Gunung Djati Bandung, 2017), Http://Digilib.Uinsgd.Ac.Id/15422/4/4_Bab1.Pdf.

${ }^{24}$ Rahmat Iswanto, "Pembelajaran Bahasa Arab Dengan Pemanfaatan Teknologi," Arabiyatuna : Jurnal Bahasa Arab, 2017, Https://Doi.Org/10.29240/Jba.V1i2.286.

${ }_{25}$ Agus Purwanto And Shofwan Hanief, "Multimedia Pembelajaran Bahasa Indonesia Untuk Mahasiswa Berbasis Animasi,” Jurnal Sistem Dan Informatika, 2016.
} 
The kinds of Arabic learning media are as follows: (1) Audio media (al-wasa'il al-samiyyah): Anything that is used to facilitate learning Arabic, can be captured and digested through the sense of hearing. For example: language, tape recorders, transistor radios, TVs, language laboratories, and so forth; (2) Visual media (al-wasa'il albashariyyah): Anything that is used to facilitate the process of language learning that can be captured and digested through the sense of sight. For example: original objects, imitation objects, pictures, various types of boards, strip stories, flash cards, text books, LCD projectors, and others; (3) Audio-visual media (al-wasa'il al-sam'iyah albashariyyah): ${ }^{26}$ Anything that can be used to facilitate language learning that can be captured and digested through the senses of hearing and vision. For example: TV, video $\mathrm{CD}$, wide layer film, multimedia language laboratory, LCD projector, internet and so on. ${ }^{27}$ Of the three types of Arabic learning media, Creative board media included in visual media. $^{28}$

Media Creative Board is a simple learning media in the form of a twodimensional rectangle of thick cardboard or scrap paper that is cut to the desired size and then coated with colored folio paper, covered with a layer of clear white duct tape, so that it can be written on it with non-permanent markers and can be deleted again to write next. Viewed from the etymological side, Creative Board means a board that is practical and flexible for learning writing skills. ${ }^{29}$

Creative Board media can be used for several Arabic learning methods with various types of teaching materials, including: (1) The use of Creative Board media with drilling methods; ${ }^{30}$ (2) The use of Creative Board media with the guesswork method image; (3) The use of Creative Board media with the guesswork method; (4) The use of Creative Board media to complete interconnected sentences; ${ }^{31}$ (5) The use of Creative

${ }^{26}$ Mahyudin Ritonga, Alwis Nazir, And Sri Wahyuni, "Pembelajaran Bahasa Arab Berbasis Teknologi Informasi Dan Komunikasi Di Kota Padang," Arabiyat : Jurnal Pendidikan Bahasa Arab Dan Kebahasaaraban, 2016, Https://Doi.Org/10.15408/A.V3i1.2879.

${ }^{27}$ Nurmadiah Nurmadiah, "Media Pendidikan," Al-Afkar : Jurnal Keislaman \& Peradaban, 2016, Https://Doi.Org/10.28944/Afkar.V5i1.109.

${ }^{28}$ Siti Jubaidah, "Efektivitas Pembelajaran Bahasa Arab Maharatul Kalam Dengan Media Komik Di Madrasah Aliyah Nasruddin Dampit," Review Pendidikan Islam 1 (2014): 247, Http://Www.Jrpi.Mdcjatim.Org/Index.Php/Jrpi/Article/View/20.

${ }^{29}$ Tseng Et Al., "Using Creative Problem Solving To Promote Students' Performance Of Concept Mapping."

${ }^{30}$ Annamária Neag, "Board Games As Interview Tools: Creating A Safe Space For Unaccompanied Refugee Children," Media And Communication, 2019, Https://Doi.Org/10.17645/Mac.V7i2.1817.

${ }^{31}$ María Inés Cabot Et Al., "Correction: Aspects Of Sustainability And Design Engineering For The Production Of Interconnected Smart Food Packaging (Plos One (2019) 14:5 (E0216555) Doi: 
Board media for writing skills on state and citizen material; ${ }^{32}$ (6) The use of Creative Board media for khobar use based on its mubtada';3 (7) The use of Creative Board media to train the development of writing ideas; ${ }^{34}(8)$ The use of Creative Board media to train the development of mufrodat through 'catch up' games, ${ }^{35}$ (9) The use of Creative Board media for sentence development; ${ }^{36}$ (10) The use of Creative Board media for the development of 'lined sentences', and others. ${ }^{37}$

\section{Discourse on Arabic Writing Skills (Maharatul Kitabah)}

Writing skills are one of the four language skills that need to be mastered in the language learning process. ${ }^{38}$ Writing skills are communicative skills in written language that have two aspects: first, proficiency in forming letters and mastering spelling; and the second is giving birth to thoughts and feelings with writing. While the core of writing skills lies in the second aspect. ${ }^{39}$ Writing is a communication activity that is carried out in the absence of tone of voice, expression, gestures and also the absence of a situation as happened in oral communication. ${ }^{40}$ But writing is able to express a variety of ideas freely by paying attention to signs of writing, such as writing techniques, language rules, logic, coherence, content, spelling, and diction. Writing skills are complex language skills,

10.1371/Journal.Pone.0216555)," $\quad$ Plos One $14, \quad$ No. $\quad 6 \quad$ (2019): $1-15$,
Https://Doi.Org/10.1371/Journal.Pone.0218337.

${ }^{32}$ Bakry And Alsamadani, "Improving The Persuasive Essay Writing Of Students Of Arabic As A Foreign Language (Afl): Effects Of Self-Regulated Strategy Development."

${ }^{33}$ Muhammad Yunus Anis, Eva Farhah, And Afnan Arummi, "The Information Structure In Arabic-Javanese Translation: Case Study In The Book Of Bidayah Al-Hidayah,” Addin 11, No. 2 (2017): 463, Https://Doi.Org/10.21043/Addin.V11i2.2317.

${ }^{34}$ Mohammed Ali Alwaleedi, Robyn M. Gillies, And M. Obaidul Hamid, "Collaborative Writing In Arabic As A Second Language (Asl) Classrooms: A Mixed-Method Study," Language, Culture And Curriculum, 2019, Https://Doi.Org/10.1080/07908318.2018.1521422.

35 Sholihah Sholihah, "Penggunaan Media Gambar Dalam Pembelajaran Mufrodat," Tarling: Journal Of Language Education, 2018, Https://Doi.Org/10.24090/Tarling.V1i1.1122.

36 Joni Meenagh, Doing Too Much: Using An Online Discussion Board, Interviews, And Developmental Vignettes To Explore Young People's Negotiation Of Their Love/Sex Relationships And New Media Environments, Doing Too Much: Using An Online Discussion Board, Interviews, And Developmental Vignettes To Explore Young People's Negotiation Of Their Love/Sex Relationships And New Media Environments, 2018, Https://Doi.Org/10.4135/9781526428271. Mapping."

${ }^{37}$ Tseng Et Al., "Using Creative Problem Solving To Promote Students' Performance Of Concept

${ }^{38}$ Muradi, "Wâqi' Ta'lîm Mahârah Al-Kitâbah Bi Indûnîsiyyâ Musykilatan Wa Hulûlan."

${ }^{39}$ Yayat Hidayat, "Teori Perolehan Dan Perkembangan Bahasa Untuk Jurusan Pendidikan Bahasa Arab,” Maharat 1, No. 1 (2018): 28, Https://Doi.Org/10.18196/Mht.113.

${ }^{40}$ Umi Hanifah, "Penerapan Model Paikem Dengan Menggunakan Media Permainan Bahasa Dalam Pembelajaran Bahasa Arab,” Ilmu Tarbiyah “At-Tajdid,” 2016. 
because they involve not only grammatical or rhetorical compilation, but also mastery of conceptual elements. $^{41}$

In the context of learning Arabic at Islamic Senior High School P.B. Soedirman 1 Bekasi, writing skills (maharatul kitabah) is a process that systematically strived for to improve the ability of students to communicate in writing in Arabic. ${ }^{42}$ Whereas the teaching technique of writing skills (maharatul kitabah) begins by introducing written words and sentences, imitating the writing model, i.e. students can mimic the same writing structure model, but different contents, rearranging words into a sentence that can be understood, complete skipped sentences, write descriptive sentences on an image, develop topics, arrange dialogues, and arrange paragraphs. ${ }^{43}$ The teaching techniques of writing essays, starting with guided writing, continued with free writing. At this stage students are trained to express their opinions by choosing words and sentence patterns freely, with guidance and direction from the teacher. While the types of essays are: simple exposition, narration, and description. ${ }^{44}$

In reviewing the results of writing and its assessment need a relatively long time, because it requires carefulness and accuracy, so that students get feedback immediately from their writings and make improvements to the notes provided by the teacher. ${ }^{45}$ It is important to note that the learning of writing skills is not merely ended in producing numbers in the assessment, but suggestions and directions about writing. One thing that should not be forgotten is to give an appreciation of the written results that have been achieved by students, both verbally and in writing on their working papers. ${ }^{46}$

\section{The Use of Creative Board to Improve Arabic Writing Skills in Islamic Senior High}

\section{School P.B. Soedirman 1 Bekasi}

The learning process using Creative Board is carried out in class $\mathrm{X}$ in the final semester 1. This is a combined manifestation of KD 3. 4 and KD 4. 4. The description of KD 3.4 is to show public buildings (al-mabani al-'ammah) that are close to the daily

\footnotetext{
${ }^{41}$ Mohd Shahrizal Nasir, Nurkhamimi Zainuddin, And Muhammad Sabri Sahrir, "Persepsi Pelajar Bukan Muslim Terhadap Pembelajaran Bahasa Arab: Ebscohost," International Journal Of Islamic Studies, 2017.

${ }^{42}$ Mohd Uzaini Mahmood And Muhammad Azhar Zailani., "Kemahiran Menulis Jumlah Bahasa Arab," O-Jie The Online Journal Of Islamic Education, 2017.

${ }^{43}$ Sitti Kuraedah, "Aplikasi Maharah Kitabah Dalam Pembelajaran Bahasa Arab."

${ }^{44}$ Hidayat, "Teori Perolehan Dan Perkembangan Bahasa Untuk Jurusan Pendidikan Bahasa Arab."

45 Normah Binti Husin, "Analisa Kesalahan Pelajar Dalam Penulisan Bahasa Arab: Menulis Resume,” In International Research Management And Innovation Conference, 2014.

${ }^{46}$ Mohd Uzaini Mahmood And Muhammad Azhar Zailani., "Kemahiran Menulis Jumlah Bahasa Arab."
} 
lives of students, taking into account social functions, text structures, and linguistic elements in transactional oral and written interaction texts, according to the context of their use. While KD 4. 4's description is to use simple texts related to public buildings (al-mabani al- 'ammah) that are close to the daily lives of students, by paying attention to social functions, text structures, and correct linguistic elements and in context.

Indicators of achieving competency in this learning are: ${ }^{47}$ writing the words / phrases that result from reading text identification, writing words / phrases then forming one sentence according to the theme with the appropriate sentence structure on the Creative Board media for sentence development, demonstrating the results of writing by raising the Creative Board media, so that it can be corrected by the teacher and recommunicating the writing. Through the use of media for the use of Creative Board media for sentence development, students can express and use simple transactional interaction written texts related to speech acts of public facilities / school buildings, by paying attention to social functions, text structures, and correct linguistic elements according to the context with a sense of curiosity, responsibility, discipline during the learning process. ${ }^{48}$

The steps in learning by using Creative Board media for developing sentences on Arabic writing skills that have been implemented in Islamic Senior High School P.B. Soedirman 1 Bekasi are as follows: ${ }^{49}$ (1) Determination of the topic: (2) Pre- (2) communicative activities, consisting of: Greeting, praying, dan checking attendance. Displaying pictures related to school environment and asking questions about the pictures. Conveying the competencies to be achieved and their benefits in everyday life. Conveying the outline of material and the steps of learning to be implemented. Presenting the scope and assessment techniques to be used. (3) Writing words. (4) Writing sentences. (5) Reflection on Learning Activities, the result of teacher evaluation is that she should equalize the standard time between a question and the next. For students, there are at least two things: 1) The intensity of drill for writing Arabic

\footnotetext{
${ }^{47}$ Bakry And Alsamadani, "Improving The Persuasive Essay Writing Of Students Of Arabic As A Foreign Language (Afl): Effects Of Self-Regulated Strategy Development."

${ }^{48}$ I. P. Mirasandi, M. Akhyar, And H. Widyastono, "Media Development On The Concept Sentence Learning Model Based Android For Students With Hearing Impairment," Journal Of Physics: Conference Series 1339, No. 1 (2019), Https://Doi.Org/10.1088/1742-6596/1339/1/012115.

${ }^{49}$ Alette Eva Opperhuizen, Kim Schouten, And Erik Hans Klijn, "Framing A Conflict! How Media Report On Earthquake Risks Caused By Gas Drilling: A Longitudinal Analysis Using Machine Learning Techniques Of Media Reporting On Gas Drilling From 1990 To 2015," Journalism Studies 20, No. 5 (2019): 714-34, Https://Doi.Org/10.1080/1461670x.2017.1418672.
} 
mufrodat and sentences must be increased; 2) The habituation of discipline in time management.

The procedure for using Creative Board media to write words is as follows: (a) The teacher provides new vocabulary that is considered difficult with regard to the theme repeatedly. (b) Students are asked to practice reading all mufrodat independently until they are able to read correctly. (c) The teacher closes access to the written form both in the book and on the LCD screen. (d) The Teacher reads mufrodat one by one. Students are asked to write it in the Creative Board media. In this phase students are given a limited time in writing of approximately 20 seconds for each mufrodat. (e) After writing, students are asked to lift the Creative Board media together. (f) The teacher checks the students' writing in front of the class or in the teacher's current position. (g) The teacher gives an assessment. Students record the results of the grade they obtained. (h) The students add up the obtained grade.

The use of Creative Board media to write sentences is as follows: (a) The teacher instructs the making of sentences with predetermined word and grammatical elements. (b) The Students write sentences in Creative Board media with a predetermined limited time. (c) The students are asked to lift Creative Board media together. (d) The teacher asks students to read the results of their writing aloud. (e) The teacher checks the results of students' writing in front of the class or the teacher's current position. (f) The teacher gives an assessment. Students record the results of the grade they obtained. (g) The students add up the obtained grade.

\section{Conclusion}

By implementing the use of Creative Board media in learning writing skills, The Arabic teacher has sought to use effective and efficient media in the learning process. On the other hand, students can also get benefit from the Creative Board media to be more enthusiastic in practicing Arabic writing, which then has implications for improving writing skills and a pleasure in learning Arabic, although most students assume that learning Arabic is a very difficult subject.Thus, the use of Creative Board learning media is feasible in the process of learning Arabic writing skills. Therefore, it is expected that future researchers will conduct further research using Creative Board learning media in learning other Arabic language skills. 


\section{Acknowledgment}

Thanks to the director of postgraduate UIN Sunan Gunung Djati Bandung and the entire academic community of Arabic language study programsfor providing support in the form of funding so that this research can take place.

\section{References}

Alwaleedi, Mohammed Ali, Robyn M. Gillies, And M. Obaidul Hamid. "Collaborative Writing In Arabic As A Second Language (Asl) Classrooms: A Mixed-Method Study." Language, Culture And Curriculum, 2019. Https://Doi.Org/10.1080/07908318.2018.1521422.

Anggara, Syamfa Agny. "Penerapan Model Project Based Learning Untuk Meningkatkan Kemampuan Menulis Siswa." Arabi: Journal Of Arabic Studies, 2018. Https://Doi.Org/10.24865/Ajas.V2i2.57.

Anis, Muhammad Yunus, Eva Farhah, And Afnan Arummi. "The Information Structure In Arabic-Javanese Translation: Case Study In The Book Of Bidayah Al-Hidayah." Addin 11, No. 2 (2017): 463. Https://Doi.Org/10.21043/Addin.V11i2.2317.

Bakry, Mohamed Saad, And Hashem Ahmed Alsamadani. "Improving The Persuasive Essay Writing Of Students Of Arabic As A Foreign Language (Afl): Effects Of Self-Regulated Strategy Development." Procedia - Social And Behavioral Sciences, 2015. Https://Doi.Org/10.1016/J.Sbspro.2015.04.742.

Cabot, María Inés, Amalia Luque, Ana De Las Heras, And Francisco Aguayo. "Correction: Aspects Of Sustainability And Design Engineering For The Production Of Interconnected Smart Food Packaging (Plos One (2019) 14:5 (E0216555) Doi: 10.1371/Journal.Pone.0216555)." Plos One 14, No. 6 (2019): 1-15. Https://Doi.Org/10.1371/Journal.Pone.0218337.

Gulam, Anfal, Mohd Faisal, Muhammad Azhar, Syed Kamaruzaman, And Wail Muin. "Writing Skill In Arabic Language Essay In Malaysian Secondary School." International Journal Of Social Science \& Human Behavior Study 2, No. 2 (2015): 169-73. Https://Doi.Org/10.15224/978-1-63248-046-0-111.

Hanifah, Umi. "Penerapan Model Paikem Dengan Menggunakan Media Permainan Bahasa Dalam Pembelajaran Bahasa Arab.” Ilmu Tarbiyah “At-Tajdid,” 2016.

Hermawan, Acep. Metodologi Pembelajaran Bahasa Arab. Bandung: Pt Remaja Rosakarya, 2018.

Hidayat, Yayat. "Teori Perolehan Dan Perkembangan Bahasa Untuk Jurusan Pendidikan Bahasa Arab.” Maharat 1, No. 1 (2018): 28. Https://Doi.Org/10.18196/Mht.113.

Huda, Nurul. "Komponen-Komponen Pembelajaran Al-Kitâbah Bahasa Arab." Al Mahāra: Jurnal Pendidikan Bahasa Arab, 2016. Https://Doi.Org/10.14421/Almahara.2016.021-01. 
Husin, Normah Binti. "Analisa Kesalahan Pelajar Dalam Penulisan Bahasa Arab: Menulis Resume." In International Research Management And Innovation Conference, 2014.

Iswanto, Rahmat. "Pembelajaran Bahasa Arab Dengan Pemanfaatan Teknologi." Arabiyatuna: Jurnal Bahasa Arab, 2017. Https://Doi.Org/10.29240/Jba.V1i2.286.

Jubaidah, Siti. "Efektivitas Pembelajaran Bahasa Arab Maharatul Kalam Dengan Media Komik Di Madrasah Aliyah Nasruddin Dampit." Review Pendidikan Islam 1 (2014): 247. Http://Www.Jrpi.Mdcjatim.Org/Index.Php/Jrpi/Article/View/20.

Kuswanto, Joko, And Ferri Radiansah. "Media Pembelajaran Berbasis Android Pada Mata Pelajaran Sistem Operasi Jaringan Kelas Xi." An Nabighoh Jurnal Pendidikan Dan Pembelajaran Bahasa Arab, 2018. Https://Doi.Org/10.32332/AnNabighoh.V20i01.1131.

Mahmudah, Siti. "Media Pembelajaran Bahasa Arab." An Nabighoh Jurnal Pendidikan Dan Pembelajaran Bahasa Arab, 2018. Https://Doi.Org/10.32332/AnNabighoh.V20i01.1131.

Martono Kurniawan, Teguh, And Dwi Nurhayati Oky. "Implementation Of AndroidBased Mobile Learning Application As A Flexible Learning Media." International Journal Of Computer Science Issues, 2014.

Maryeni, Lucy, Syarifah Nur Siregar, And Yenita Roza. "Development Of ComputerBased Learning Media Using Mind Map For Learning Mathematics In Topics Of Rectangle And Triangle At Secondary School” 2019, No. July 2019 (2020): 73-84.

Meenagh, Joni. Doing Too Much: Using An Online Discussion Board, Interviews, And Developmental Vignettes To Explore Young People's Negotiation Of Their Love/Sex Relationships And New Media Environments. Doing Too Much: Using An Online Discussion Board, Interviews, And Developmental Vignettes To Explore Young People's Negotiation Of Their Love/Sex Relationships And New Media Environments, 2018. Https://Doi.Org/10.4135/9781526428271.

Mirasandi, I. P., M. Akhyar, And H. Widyastono. "Media Development On The Concept Sentence Learning Model Based Android For Students With Hearing Impairment." Journal Of Physics: Conference Series 1339, No. 1 (2019). Https://Doi.Org/10.1088/1742-6596/1339/1/012115.

Mohd Uzaini Mahmood, And Muhammad Azhar Zailani. "Kemahiran Menulis Jumlah Bahasa Arab." O-Jie The Online Journal Of Islamic Education, 2017.

Muradi, Ahmad. "Wâqi' Ta'lîm Mahârah Al-Kitâbah Bi Indûnîsiyyâ Musykilatan Wa Hulûlan." Arabiyat : Jurnal Pendidikan Bahasa Arab Dan Kebahasaaraban, 2018. Https://Doi.Org/10.15408/A.V5i1.7795.

Musthafa, Izzuddin, And Acep Hermawan. Metodologi Penelitian Bahasa Arab (Konsep Dasar, Strategi, Metode, Teknik). Bandung: Pt Remaja Rosakarya, 2018.

Nalaratih, Nur Indah, And Ali Mudlofir. “ تطبيق وسائل اللوحة المغناطيسية لترقية مهارة الكتابة لتلاميذ Jurnal Al Bayan: Jurnal Jurusan Pendidikan Bahasa Arab, 12 (1): 58-72 (2020)| 70 
الفصل الثامن بمدرسة واحد هانشم المتوسطة سور ابايا." Alfazuna: Jurnal Pembelajaran Bahasa Arab Dan Kebahasaaraban 2, No. 2 (2018): 203-12.

Nasir, Mohd Shahrizal, Nurkhamimi Zainuddin, And Muhammad Sabri Sahrir. "Persepsi Pelajar Bukan Muslim Terhadap Pembelajaran Bahasa Arab: Ebscohost." International Journal Of Islamic Studies, 2017.

Neag, Annamária. "Board Games As Interview Tools: Creating A Safe Space For Unaccompanied Refugee Children." Media And Communication, 2019. Https://Doi.Org/10.17645/Mac.V7i2.1817.

Noor, Hilmi M. "Penggunaan Media Komik Dalam Pembelajaran Bahasa Arab Materi Hiwar Dan Pengaruhnya Pada Prestasi Siswa Dalam Pembelajaran Bahasa Arab." $\begin{array}{llll}\text { Uin Sunan } \quad \text { Gunung } & 2017 .\end{array}$ Http://Digilib.Uinsgd.Ac.Id/15422/4/4_Bab1.Pdf.

Nurmadiah, Nurmadiah. "Media Pendidikan." Al-Afkar: Jurnal Keislaman \& Peradaban, 2016. Https://Doi.Org/10.28944/Afkar.V5i1.109.

Opperhuizen, Alette Eva, Kim Schouten, And Erik Hans Klijn. "Framing A Conflict! How Media Report On Earthquake Risks Caused By Gas Drilling: A Longitudinal Analysis Using Machine Learning Techniques Of Media Reporting On Gas Drilling From 1990 To 2015." Journalism Studies 20, No. 5 (2019): 714-34. Https://Doi.Org/10.1080/1461670x.2017.1418672.

Ping, Ng Sau, And Mahendran Maniam. "The Effectiveness Of Facebook Group Discussions On Writing Performance: A Study In Matriculation College." International Journal Of Evaluation And Research In Education (Ijere), 2015. Https://Doi.Org/10.11591/Ijere.V4i1.4489.

Purwanto, Agus, And Shofwan Hanief. "Multimedia Pembelajaran Bahasa Indonesia Untuk Mahasiswa Berbasis Animasi.” Jurnal Sistem Dan Informatika, 2016.

Raut, Vishranti, And Prafulla Patil. "Use Of Social Media In Education: Positive And Negative Impact On The Students." International Journal On Recent And Innovation Trends In Computing And Communication, 2016.

Ritonga, Mahyudin, Alwis Nazir, And Sri Wahyuni. "Pembelajaran Bahasa Arab Berbasis Teknologi Informasi Dan Komunikasi Di Kota Padang." Arabiyat : Jurnal Pendidikan Bahasa Arab Dan Kebahasaaraban, 2016. Https://Doi.Org/10.15408/A.V3i1.2879.

Rosdiana, Rosdiana. "Pengembangan Media Pembelajaran Berbasis Komputer." $A l$ Khwarizmi: Jurnal Pendidikan Matematika Dan Ilmu Pengetahuan Alam, 2018. Https://Doi.Org/10.24256/Jpmipa.V1i2.95.

Setiadi, Syamsi. "Peningkatan Keterampilan Kitabah Arabiyah Mahasiswamelalui Metode Tutor Sebaya.” Jurnal Al Bayan: Jurnal Jurusan Pendidikan Bahasa Arab, 2017. Https://Doi.Org/10.24042/Albayan.V9i1.1094. 
Sholihah, Sholihah. "Penggunaan Media Gambar Dalam Pembelajaran Mufrodat." Tarling: Journal Of Language Education, 2018. Https://Doi.Org/10.24090/Tarling.V1i1.1122.

Sitti Kuraedah. "Aplikasi Maharah Kitabah Dalam Pembelajaran Bahasa Arab." AlTa'dib, 2015.

Sugiyono. Metode Penelitian Kuantitatif Kualitatif Dan R\&D. Bandung: Alfabeta, 2016.

Tambunan, Hardi. "The Effectiveness Of The Problem Solving Strategy And The Scientific Approach To Students' Mathematical Capabilities In High Order Thinking Skills." International Electronic Journal Of Mathematics Education 14, No. 2 (2019): 293-302. Https://Doi.Org/10.29333/Iejme/5715.

Tseng, Kuo Hung, Chi Cheng Chang, Shi Jer Lou, And Pi Shan Hsu. "Using Creative Problem Solving To Promote Students' Performance Of Concept Mapping." International Journal Of Technology And Design Education, 2013. Https://Doi.Org/10.1007/S10798-012-9230-8. 